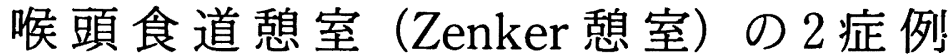

\author{
嶋 崎 孝 嗣*, 吉田 義一* \\ 野 村 和**
}

\section{Two Cases of Pharyngoesophageal Diverticulum (Zenker's Diverticulum)}

\author{
Takatsugu Shimazaki, M.D., ${ }^{*}$ Yoshikazu Yoshida, M.D., ${ }^{*}$ \\ and Yasushi Nomura, M.D.** \\ *Department of Otorhinolaryngology and Head and Neck Surgery, School of \\ Medicine, Kurume University, Fukuoka, and ${ }^{* *}$ Department of Head \\ and Neck Surgery, Kyushu National Cancer Center, Fukuoka
}

In Japan, Zenker's diverticulum is a rare disease, with less than fifty cases thus far reported. The authors reported two cases of Zenker's diverticulum and discussed their clinical features and the cause of this disease and its treatment. A 69-year-old woman complained of swallowing difficulty, showed stenosis of the pharyngoesophageal region on fluoroscopic examination. After removing food under esophagoscopy, a large diverticulum was found. The second case, a 61-year-old man with a severe "lump" sensation of the throat was introduced to our clinic by a private practitioner. The patient received an endoscopic examination, however, a flexible fiberscope could not be inserted beyond the hypopharynx. Radiopharyngography demonstrated Zenker's diverticulum. In each case, diverticulectomy was performed according to Montgomery's technique without cricopharyngeal myotomy. The symptoms disappeard after the operation. Both pathological examinations diagnosed a pulsion diverticulum with a moderate chronic inflammatory infiltrate. There was no malignant tissue in either case.

\section{Key words : Zenker, 勆室, 咽頭食道, 讌下障害}

\section{I .はじめに}

Zenker 螅室は, 下咽頭収縮筋のうち輪状咽 頭筋斜走部と, 横走部の間の Lannier. Hackerman 間隙より圧出性に突出して生じる 悡室とされている ${ }^{1,2)}$ 。欧米では数多くの報告が あるが3,4)，本邦では現在まで，その症例報告数 が50例に満たない比較的稀な疾患である ${ }^{5,6)}$ 。そ

*久留米大学医学部耳鼻咽喉科学教室, **九州がんセ ンター頭頸科

別刷請求： $\mathbf{T} 830$ 福岡県久留米市旭町 67

久留米大学医学部耳鼻咽喉科 嶋崎孝嗣

投稿受付：1994年10月 3 日
の病因, 病態生理, 外科的治療法については今 日でも多くの異論がある8)。今回われわれは, 嚥 下障害を訴え手術によって改善された本症の 2 例を経験したので，若干の文献的考察を加えて 報告する。

\section{II . 症例}

症例 $1 ： 69$ 歳の女性

初 診: 1989年 6 月16日

主 訴：嶼下痛, 嚥下困難

家族歴ならびに既往歴：特記すべきことはな (v)

現病歴： 1 週間前より嬩下痛と軽度の全身倦 
总感を自覚, 近くの内科医を受診し投薬を受け た。しかし曖下痛は軽快せず, 初診前日より喉 頭閉塞感も加わり曖下困難となり, 全身倦怠感 が増悪, さらに左耳への放散痛をきたした。水 様物のみしか摂取できなくなり当科を受診し た。

初診時所見：体格中等度，栄養状態おおむね 良好。顔色不良。局所所見として, 両側耳, 鼻 腔内には異常なく, 喉頭粘膜は全体的に浮腫状 腫脹, 下咽頭には梨状陥山の狭小と唾液貯留が 著しく認められた。頸部は輪状軟骨の左側面と 後面に疼痛と抵抗を認めたが, リンパ節腫脹, 腫瘤などは触知しなかった。

検査所見：(1)一般血液検查：白血球7500, 赤 血球 $366 \times 10^{4}$, 血色素 $11.8 \mathrm{~g} / \mathrm{dl}$ で, 血沈は $71 /$ $102 \mathrm{~mm}$ と著しく元進していた。

(2) X線検查：頸部側面単純 $X$ 線撮影では, 頸 椎前縁と気管後壁間の距離が気管前後幅の 1.6 倍を示した。またバリウムによる食道透視検査 では前後面像で, 頸部食道左側に腫瘍状の異常 陰影を認めた（図 1 )。

以上の所見より，下咽頭癌または異物症が疑
われたため, 精査加療の目的で入院となった。

(3)食道直達鏡検查：下咽頭, 食道入口部を精 査するため全身麻酔下に食道鏡検査を行った。 披裂部を前上方に押し上げたところ，食塊が詰 まった秝室を見い出した。食塊除去後, 再度食 道透視検查を行ったところ, 第 6 頸椎から第 7 頸椎の高さで食道の左後方に突出する大きな鄎 室像を認めた（図 2 )。

(4)CT 検査：透視後 1 日おいた撮影で, 第 6 頸椎から第 7 頸椎の高さで, 食道の左後方に突 出するバリウムによる high density 陰影を認 めた（図 3 )。

これらの所見より，頸部食道の左後方に突出 する急性炎症を併発したZ Zenker の㮩室と診断 した。

その後の経過：自覚症状（嚥下痛, 喉頭閉塞 感など）ならびに他覚的所見より手術適応と判 断し, 全身麻酔下に Montogomery の術式》に したがって憩室切除術を施行した。

手術は, 皮切を左胸鎖乳突筋の前縁に沿って, 輪状軟骨の高さを中心に約 7 センチ行った。甲 状腺を上前方に牽引，甲状軟骨下角にフックを
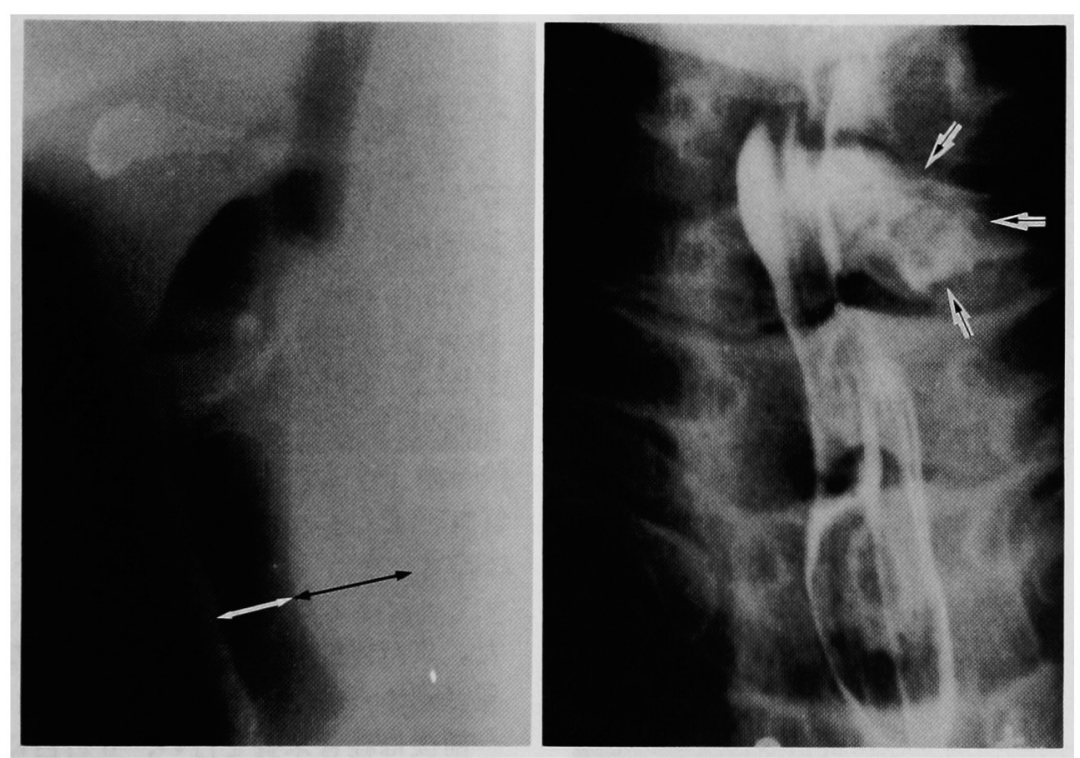

図 1 症例 1

左図：頸部側面単純X線像。頸椎前緑から気管後壁間の距離が，気管前後幅より 拡大している (矢印)。

右図：X線バリウム透視所見(前後像)。頸部食道左側に腫瘍状の異常陰影を認め る (矢印)。 


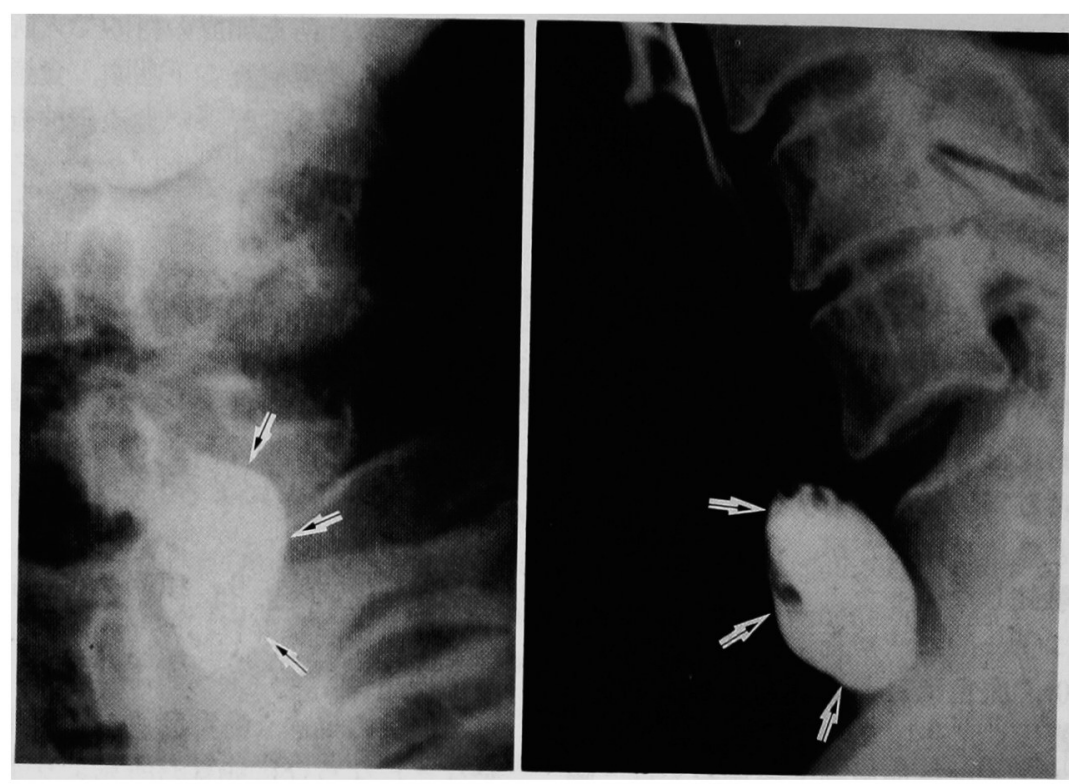

図 2 症例 1 の食塊除去後のX線バリウム透視所見 (左：前後像, 右：側面像) 第 6 頸椎から第 7 頸椎の高さで食道の左後方に突出する熄室像を認める (矢印)。

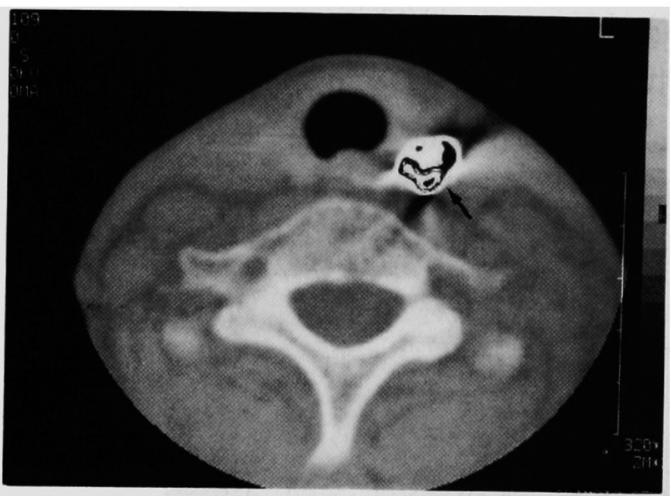

図 3 症例 1 の頸部 CT 所見

食道の左後方にバリウムが貯留した high density 陰影を認める (矢印)。

かけ喉頭を翻転し，反回神経を確認し，息室を ひっぱり茎部筋層を剝離した。次に切離予定部 位に保持用の系をかけ, ペアンで㣣んで切断し た。創面消毒後, 二重に結節縫合を行った。さ らに外膜と周囲筋層を密に縫合し，ドレーンを 留置し手術を終了した。切除標本の大きさは $12 \times 17 \mathrm{~mm}$ であった(図 4-A)。

病理組織像は压出型䕀室で, 重層扁平上皮の 上皮下に線維組織と少量の薄い筋組織がみられ

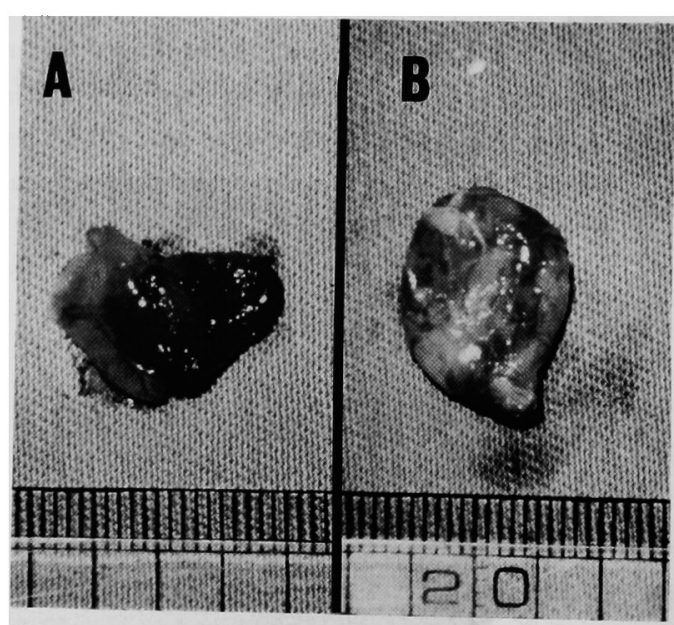

図 4 切除標本写真

A : 症例 $1, \mathrm{~B}$ : 症例 2 。

た。また慢性炎症所見も認められたが，悪性所 見は認められなかった（図 5 )。

術後は経管栄養を行い, 8 日目に食道透視検 査を施行, 造影剤の通過は良好で停滞, 漏れは 見られなかった。その後自覚症状の改善をみた ので退院した。 


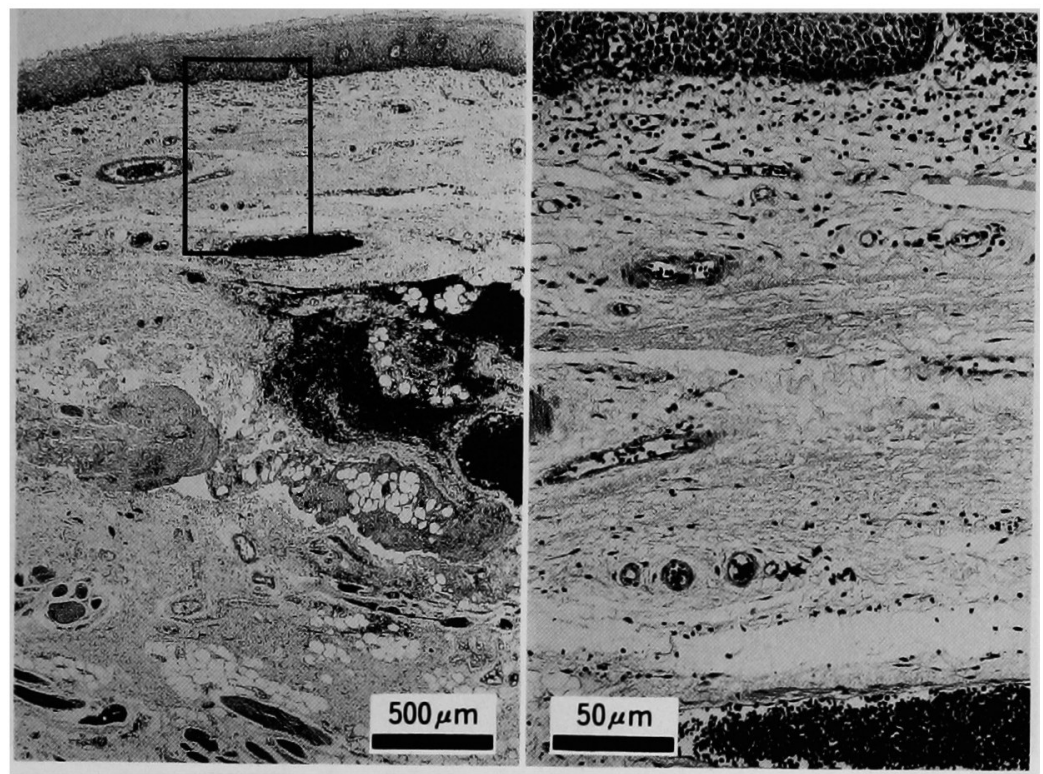

図 5 症例 1 の病理所見

右図は左図実線枠の拡大所見。上方に重層扁平上皮，下方に筋組織の一部が見 られる。中央右に黒く見えるのは出血あと。軽度慢性炎症所見のみで, 悪性所 見は認められない。

症例 $2 ： 66$ 歳男性

初 診: 1990年 5 月 7 日

主 訴：咽喉部の閉塞感

家族歴ならびに既往歴：特記すべきことはな ()

現病歴：3カ月前より徐々に胸やけ，喉頭閉 塞感，ならびに嚥下困難を自覚し，内科医を受 診した。その際胃内視鏡検査を受けたが, 内視 鏡插入時,下咽頭を過ぎたあたりで抵抗があり， 食道への挿入が不可能であるという理由で当科 を紹介された。

現 症：体格中等度, 栄養状態良好。喉頭鏡 検査で梨状陥凹に唾液貯留を認めた。頸部には 腫瘤、リンパ節腫脹は触れなかったが, 左側の 輪状軟骨後方には圧痛があり抵抗を認めた。そ の他には特記すべき所見はなかった。

検査所見：(1)一般血液検査：異常を認めなか った。

(2) X線検查：側面単純 $X$ 線撮影で, 第 7 頸椎 前方に空気像が見られた(図 6)。また食道バリ ウム透視では第 6 頸椎から第 7 頸椎の高さで, 食道の左後方に突出する大きな㮩室像を認めた

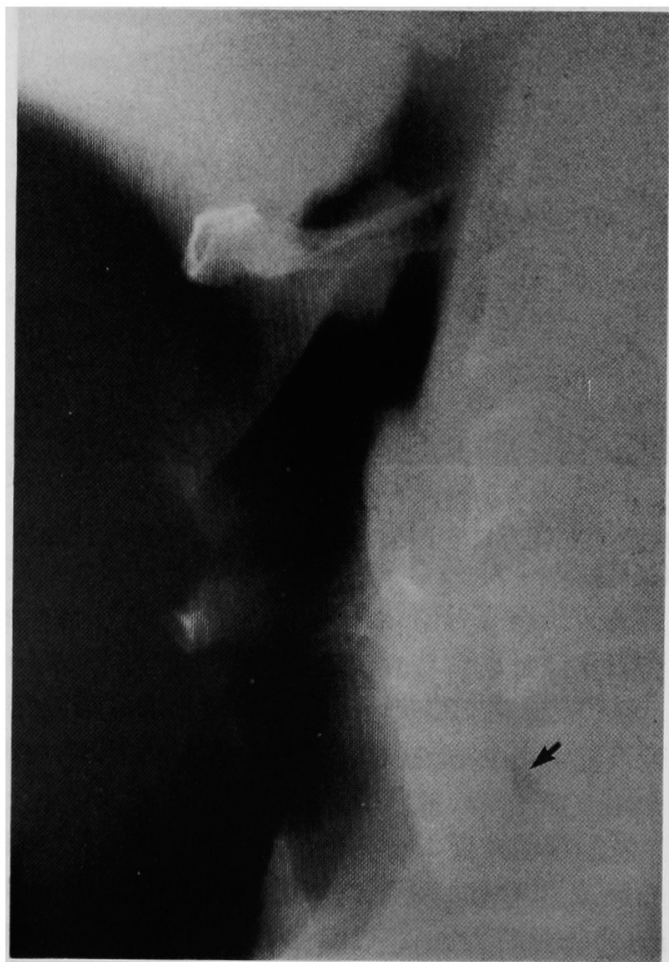

図 6 症例 2 の頸部側面単純 $X$ 線像 第 7 頸椎前方に空気像が見られる (矢印)。 

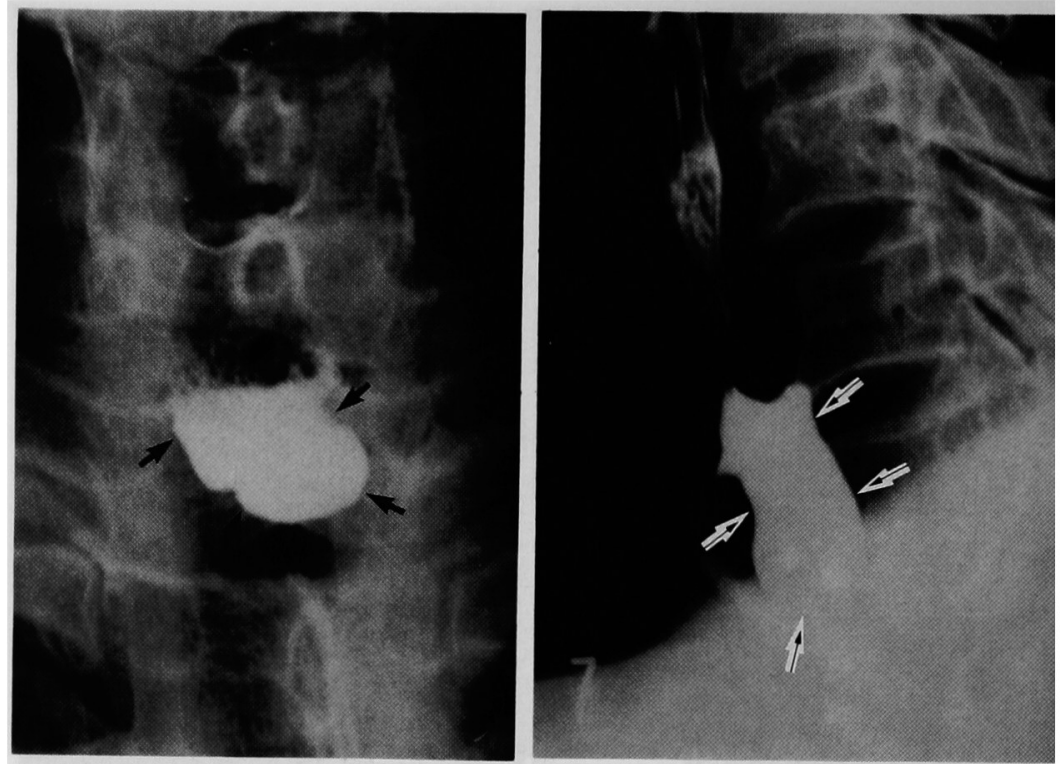

図 7 症例 2 のX線バリウム透視所見（左：前後像, 右：側面像）

第 6 頸椎から第 7 頸椎の高さで食道の左後方に突出する大きな㮩室像を認める (矢印)。

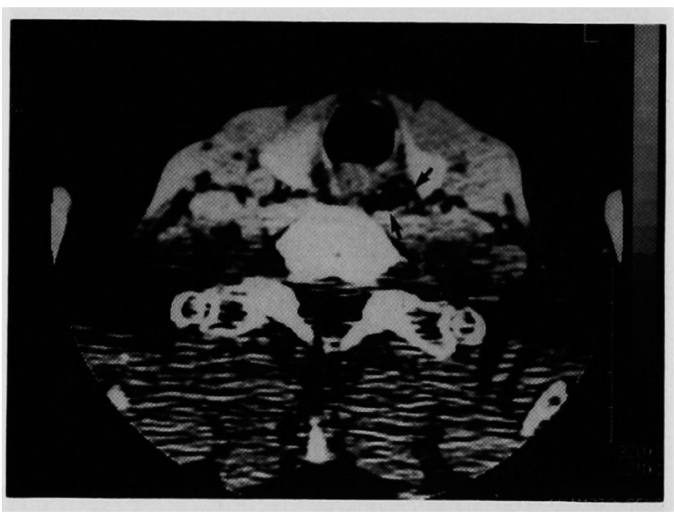

\section{図 8 症例 2 の澒部 CT 所見}

食道の左後方に air density を呈する陰影を認める (矢印)。

\section{(図 7 )。}

(3)CT 検査 : 第 6〜 7 頸椎の高さで食道の左 後方に air density を呈する陰影を認めた（図 $8)$ 。

(4)筋電図検查 : 輪状咽頭筋, オトガイ舌骨筋 の筋電図では, 嚥下時の筋弛緩時間は約 500 msec と正常範囲で, spasm の所見は認められ なかった（図 9 )。

以上の所見よりZenker 敗室と診断した。

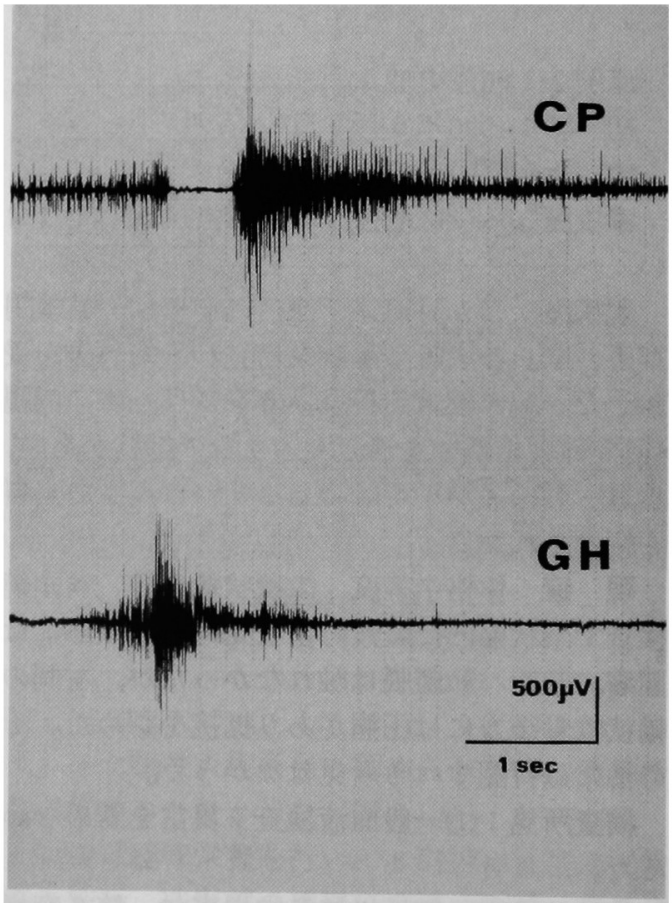

図 9 症例 2 の輪状咽頭筋（上段）ならびにオトガ イ舌骨筋 (下段) より誘導した筋電図所見 筋弛緩時間は約 $500 \mathrm{msec}$ と正常範囲で spasm の所 見は認められない。 

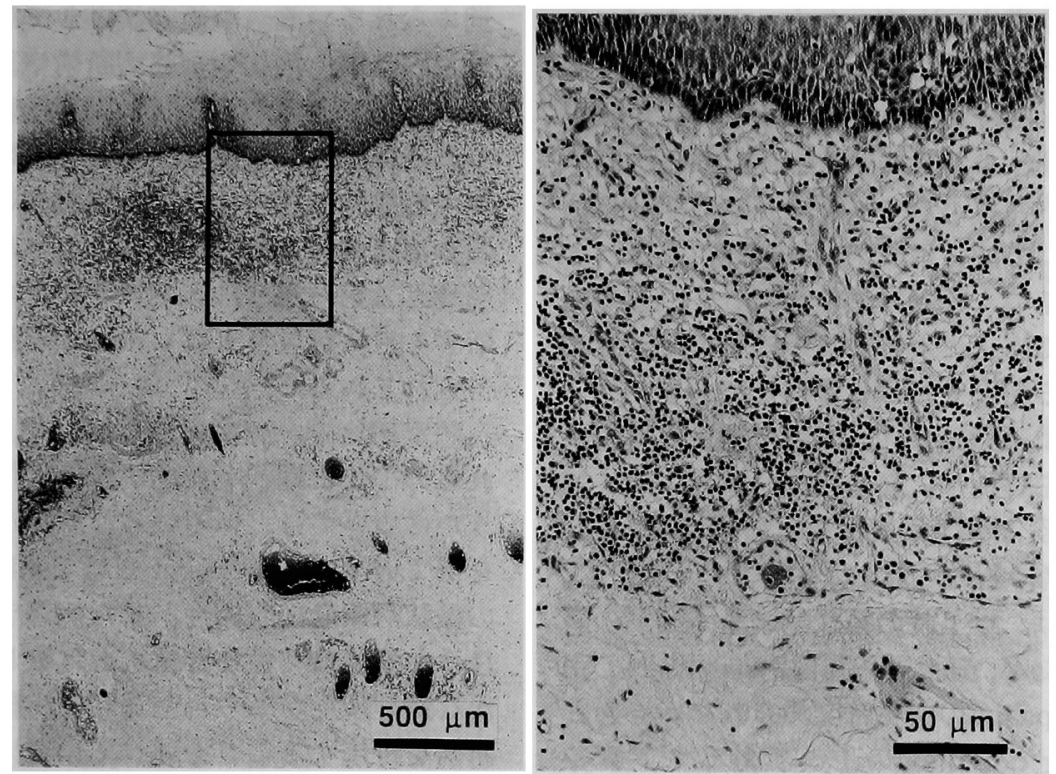

図10 症例 2 の病理所見

右図は左図実線枠の拡大所見。慢性炎症所見がみられる。悪性所見は認められない。

その後の経過：嚥下困難, 喉頭閉塞感等の自 覚症状と検查所見より, 手術適応と判断し, 症 例 1 と同様に媳室切除術を行った。

手術は症例 1 と同様に進め, 左胸鎖乳突筋の 前縁の切開後, 悡室を確認し切除した。切除標 本の大きさは $14 \times 17 \mathrm{~mm}$ であった（図 4-B）。

顋室の病理組織像は, 顋室内壁は慢性炎症性 細胞の浸潤を伴った重層扁平上皮でおおわれて いたが，悪性所見は認められなかった（図10）。

術後は経管栄養を行い，8日目に食道透視検 査を施行したが, 異常を認めなかった。以後症 状も軽快したため退院した。

1993年12月現在, 両症例とも㮩室の再発は見 ていない。

\section{III. 考 察 \\ 1. 概 要}

咽頭食道㮩室は, 1769年 Ludlow によって初 めて報告されたが, 病理学的記述は, 1874年 Zenker とZiemssen により初めて行われ, Zenker 賏室としてよく知られるようになった ${ }^{3)}$ 。欧 米では数多くの報告がみられるが7，本邦では 比較的稀な疾患である。Ekberg ら ${ }^{8)}$ は嚥下障 害を訴えた患者 854 人の食道透視検査で, Zen- ker 賏室の認められたものは $2 \%$ (20人)，また Macmillian は1.8\%であったとしている9 。

大木らの集計によれば, 1988年までの本邦で の報告例は33例で, 平均年齢56.3歳, 男女比は $12 ： 11$ と差がないが, 欧米では平均年齢60歳代 で男女差は 2：1 から 3：1 と男性に多いとされ ている51。1990年泉の報告でも，本邦での報告は 50 例に満たないという6)。

\section{2. 成 因}

Zenker 鄎室の成因については先天的な解剖 学的異常, 二次的老化による壁の萎縮, 輪状咽 頭筋機能不全, 輪状咽頭筋 spasm などの報告が 見られるが,一定の見解は得られていない5)。 Montgomery は原因として輪状咽頭筋の spasm, 頸部食道の筋層ならびに下咽頭収縮筋 の先天性欠損の 3 つをあげた。さらに㮃室は最 初, 下咽頭収縮筋下部々輪状咽頭筋上部との間, 輪状咽頭筋の直下で食道筋（輪状に走る部）の 欠損する部，および輪状咽頭筋の斜走部と横走 部の 3 か所で発生するとしている。3つめの部 位は輪状咽頭筋の斜走部は咽頭神経叢の支配に 対し，横走部は反回神経の分枝の支配で，筋の 共同運動の欠如から Herniation あるいは Pulsion が生じるものと思われる。いずれにしても 
初めは後方に突出し次第に左方へ向かうが，そ の理由ははっきりしていないという7。

河田らは, 内圧䕀室と呼ばれるものは生理的 狭窄部の上部，または病的狭窄の上部において 筋層に先天的発育不全や筋線維分離(間隙形成) があったり，あるいは異物の長期間の嵌在，ま たは損傷に基づく菲弱な部位があると, 食物の 通過に際して内圧により粘膜が筋層を貫き外方 に圧出される結果生じると考察している ${ }^{10)}$

Lerut らは, 酵素組織化学, 免疫組織化学的に 輪状咽頭筋を解析し, 筋の収縮, 肥大, サイズ の不同, 壊死, 線維化, 炎症などの変性が, Zenker 秘室患者で認められたと報告している゙1)。

症例 2 では，與下時の輪状咽頭筋 (CP) の筋 電図をとったが, 筋弛緩時間は約 $500 \mathrm{msec}$ と正 常範囲で, spasm の所見は認められなかった。 また leading complexの1つであるオトガイ 舌骨筋 $(\mathrm{GH})$ の時間差も $800 \mathrm{msec}$ 以下と正常範 囲にあった（図 9 参照）。

\section{3 . 症状}

症状としては，䁩下障害，未消化物の逆流， 咽喉の閉塞感，口臭，水を飲むときの喉なり， 咳嗽, 繰り返し起こる嚥下性肺炎, 体重減少な どがあげられているが, 無症状に経過していて, 偶然 $X$ 線検査で見つかった例も報告されてい る $^{7,12)}$ 。今回の報告では, 症例 1 は当初悪性腫瘍, 異物を疑い検査を進めていくうちに䕀室の存在 が分かったこと, 症例 2 は内視鏡挿入時のトラ ブルで，内科医より紹介されるという経過をと つた。

\section{4. 診断}

喉頭高圧 $\mathrm{x}-\mathrm{p}$ で頸椎前に空気像が見られた り, 頸部 CT 検査で食道の後方に air density を 呈する陰影を認めることでも疑われるが(図 6 , 8 参照), 内視鏡検査で悡室を確認したり, 食道 透視検査で䕀室を造影することで確定する。時 に輪状咽頭筋の spasm が見られる7)。本症例 1 のように㮩室内に異物が充満している場合は, それを取り除いてから明らかになる場合もあ る。

\section{5. 治療}

治療は，穿孔・出血またはその危険性のある もの, 合併症特に悪性変化のあるもの, 愁訴の 強いもの, 媳室の大きいものには手術的治療が
進められている。手術方法として㲘室切除術, 㮩室固定術, 輪状咽頭筋切断術や, 最近では内 視鏡を用いた輪状咽頭筋切断術が行われてい る。内視鏡的治療法は，隔壁上部の括約筋を分 離する目的で行われるが, 最近先端が 2 分した 䕀室治療用スコープが種々考案され, 電気メス, 炭酸ガスレーザー，またステープルで隔壁を切 断する方法が取り入れられ，よい治療成績が報 告されている13,14)。

顋室切除術, 賏室固定術単独で, あるいはこ れらの術式に輪状咽頭筋切断術を併施するかど うかについては，いろいろな意見があり，結論 を得ていない ${ }^{3,15)}$ 。Lerut らは Zenker 賏室患者 の輪状咽頭筋の収縮性，また病理学的な酵素特 性, 免疫組織特性を健常人と比較し $95 \%$ に明ら かな病理所見がみられたとして, 輪状咽頭筋切 断術を併施することを述べている11)。彼らが調 査した390例のZenker 想室手術症例のうち, 㮩 室固定術単独で行った184例の $21.7 \%$ が手術後 合併症を起こしたのに対し, 媳室固定術に輪状 咽頭筋切断術を併施したものでは, 術後176例の うち $11.3 \%$ にしか合併症を認めなかったとして (る ${ }^{11)}$ 。Huang らは以前, 一期的䕀室切除後に 咽頭食道息室が再発することは稀であり, Mayo Clinicで手術を行った888例中再発は32 例 $(3.2 \%)$ であったと報告しているが16)，最近 では憩室切除術に輪状咽頭筋切断術を併施し, 術後死亡率, 重篤な合併症が減少し, 入院期間 が短縮したと述べている17)。

今回の報告では䕀室切除術のみを行ったが, 手術も比較的簡単で入院期間も短くてすむこと から, 嚥下痛, 嚥下困難などの愁訴の強い例に は, 数室切除術（切除の不確実な例では輪状咽 頭筋切断術も併施）などの手術療法が必要と思 われる。また䕀室に悪性腫勯の合併も報告され ており 4 418), 必ず病理検査が必要である。最近透 視検査をせずに, 最初から内視鏡検査を行うケ 一スも増えてきており，穿孔などの偶発症を防 ぐ意味でも, 㮩室のことをたえず念頭において 検査を進めることが必要である。

\section{IV，結語}

日本人には珍しい比較的大きな Zenker 䈍室 の69歳女性と61歳男性の 2 症例を報告した。両 
症例とも第 6, 7 頸椎前方の左側にあり，1例 目は食物が䡯室内に入り噯下困難を呈し，2例 目は強い閉塞感を訴え, 内科で内視鏡検査に際 して, 先端が食道入口部を通過しえなかったこ とから判明した。悡室切除後は順調な経過をと り再発の兆しはない。また病理組織検査では, 悪性変化はなく圧出性のものとわかった。本症 の成因，治療法について若干の考察を加えた。

稿を終えるにあたり，ご校閱いただきました久留 米大学耳鼻咽喉科学教室平野実教授に梁謝します。

本論文の要旨は, 第42回日本気管食道科学会 $(1990$ 年，鹿児島）にてロ演した。

\section{文献}

1) Santovin, K.K., Conlon, S.W., and Campbell, A.D. : Zenker's diverticulum. Surgical evolution, perioperative implications. Aorn. J., $57: 234-246,1993$.

2 ）木原 彊, 張 泰昌, 星加和徳：消化管の X線 像. XIII. Zenker 惒室. 総合臨床, 36 ：25852590, 1987.

3 ) Gregoire, J., and Duranceau, A. : Surgical management of Zenker's diverticulum. Hepatogastroenterology, 39:132-138, 1992.

4 ) Payne, W.S. : The treatment of pharyngoesophageal diverticulum: The simple and complex. Hepatogastroenterology, $39: 109-114$, 1992.

5 ) 大木一郎, 秋谷寿一, 阿久沢巨 : Zenker 款室. 消化器科, $10 ： 213-219,1989$.

6 ）泉 明夫：食道 Zenker 数室の 1 例. 島根医学, $10: 86-88,1990$.

7 ) Montgomery, W.W. : Surgery of the upper respiratory system vol. 2, pp. 283-296, Lea \& Febiger, Philadelphia, 1973.

8 ) Ekberg, O., and Wahlgren, L. : Dysfunction of pharyngeal swallowing. A cineradiographic investigation in 854 dysphageal patients. Acta Radiol., 26 : 389-395, 1985.

9 ）新井裕二, 鍋谷欣市, 相馬 智：咽頭食道䕀室 症例の術前・術後内視鏡所見. Prog. Digest. Endosc., $11: 60,1977$.

10）河田政一, 向野興雄：胸部食道唵室 10 症例, 特 にその食道像について。耳鼻と臨床， $7: 177$, 1961.

11) Lerut, T., van Raemdonck, D., and Guelinckx, P. : Zenker's diverticulum: Is a myotomy of the cricopharyngeus useful ? How long should it be ? Hepatogastroenterology, $39: 127-131$, 1992.

12）門脇敬一, 横山道明, 竹内裕美：Zenker 悡室の 1 症例. 耳鼻, $30 ： 385-390,1984$.

13) Collard, J.M., Otte, J.B., and Kastens, P.J. : Endoscopic stapling technique of esophagodiverticulostomy for Zenker's diverticulum. Ann. Thorac. Surg., $56: 573-576$, 1993.

14) Holinger, L.D., and Benjamin, B. : New endoscope for (laser) endoscopic diverticulotomy. Ann. Otol. Rhinol. Laryngol., 96:658-660, 1987.

15) Barthlen, W., Feussner, H., and Hannig, C. : Surgical therapy of Zenker's diverticulum: Low risk and high efficiency. Dysphagia, 5 : 13-19, 1990.

16) Huang, B., Payne, W., and Cameron, A. : Surgical management for recurrent pharyngoesophageal (Zenker's) diverticulum. Ann. Thorac. Surg., 37 : 189-191, 1984.

17) Payne, W., and King, R. : Pharyngoesophageal (Zenker's) diverticulum. Surg. Clin. N. Am., 63: 815-824, 1983.

18) Bowdler, D., and Stell, P. : Carcinoma arising in posterior pharyngeal pulsion diverticulum (Zenker's diverticulum). Br. J. Surg., 74 : 561$563,1987$. 